\title{
Squamous metaplasia of the rectum associated with ulcerative colitis diagnosed using narrow- band imaging
}

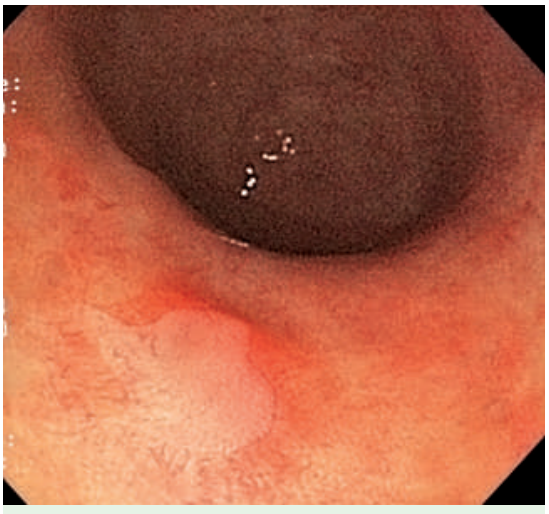

Fig. 1 A small whitish area with a clearly demarcated border, about $5 \mathrm{~mm}$ in size, was found in the lower part of rectum at colonoscopy. Small reddish spots were seen within the whitish area, which was surrounded by hyperplastic normal rectal mucosa.

A 61-year-old-man with ulcerative colitis attended our hospital for a surveillance colonoscopy. He had been diagnosed with left-sided ulcerative colitis, which had been well controlled by oral 5-aminosalicylic acid for 6 years. No active inflammation was detected in the colon or rectum at colonoscopy, but a small whitish area with a clearly demarcated border, about $5 \mathrm{~mm}$ in size, was found in the lower part of rectum ( $\bullet$ Fig. 1). Small reddish spots were seen within the whitish area, which was surrounded by hyperplastic normal rectal mucosa. Chromoendoscopy using $0.4 \%$ indigo carmine dye highlighted the demarcation line of the whitish area ( Fig. 2). Narrow-band imaging showed dark-brown dots corresponding to the reddish spots seen in the conventional view, and these were considered to resemble the intraepithelial capillary loops observed in normal esophageal squamous epithelium ( Fig. 3) [1]. A biopsy specimen was taken from the whitish area for histological evaluation, and this was reported as squamous-cell epithelium without dysplasia. A final diagnosis of squamous metaplasia associated with ulcerative colitis was made.

Squamous metaplasia in the colorectum is very rare. In most cases this abnormality is found in the rectum or sigmoid colon

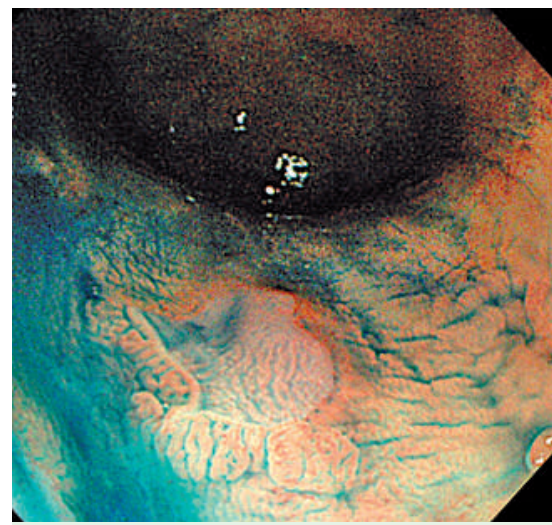

Fig. 2 Chromoendoscopy using $0.4 \%$ indigo carmine dye highlighted the border of the whitish area.

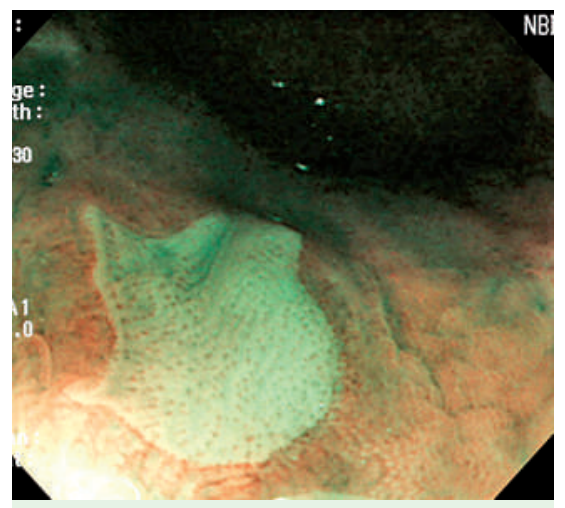

Fig. 3 Narrow-band imaging showed darkbrown dots within this area which corresponded to the reddish spots seen at conventional colonoscopy. These dots were similar in appearance to the intraepithelial capillary loops that are seen in normal esophageal squamous epithelium.

[2]. The presence of squamous epithelium in the colorectum is presumed to represent proliferation of reserve cells after mucosal injury, heterotopic nests of squamous epithelium, or secondary squamous metaplasia [3]. Squamous metaplasia without dysplasia has been reported in the setting of ulcerative colitis, usually in the distal rectal mucosa, but its characteristic endoscopic appearance has been described only rarely [2]. A finding of a thin whitish area with a distinct margin at conventional colonoscopy is reported to be a clue to the diagnosis $[4,5]$. Lugol chromoendoscopy has been used for confirmation of the conventional colonoscopic findings [4]. Recently, narrowband imaging has been developed as a new endoscopic technique for improved visualization of mucosal surfaces and capillary networks without the use of dyes. In this case, brownish dots detected by narrow-band imaging within the whitish area mimicked the appearance of intraepithelial capillary loops seen in normal esophageal squamous epithelium, and so narrow-band imaging predicted the histology.

Although the progression of metaplasia to dysplasia to carcinoma has not yet been established for primary squamouscell colorectal carcinoma because of its rarity, sporadic cases of squamous metaplasia associated with dysplasia and/or primary squamous-cell carcinoma have been reported [2], and this patient should therefore be carefully followed up. Narrow-band imaging with magnification is a simple and effective method that can be used to detect the presence of the morphological changes of intraepithelial capillary loops for cancer surveillance.

Endoscopy_UCTN_Code_CCL_1AD_2AD

\section{K. Fu, Y. Tsujinaka, Y. Hamahata, \\ K. Matsuo, O. Tsutsumi}

Department of Coloproctology, TokatsuTsujinaka Hospital, Chiba, Japan 


\section{References}

1 Yoshida T, Inoue H, Usui S et al. Narrow-band imaging system with magnifying endoscopy for superficial esophageal lesions. Gastrointest Endosc 2004; 59: 288 - 295

2 Nishi T, Weinstein WM, Makuuchi H. Squamous cell metaplasia in the rectum: a case report and review of the medical literature. Tokai J Exp Clin Med 2004; 29: 163 - 166

3 Zirkin RM, McCord DL. Squamous cell carcinoma of the rectum: report of a case complicating chronic ulcerative colitis. Dis Colon Rectum 1963; 6: 370-373
4 Maruoka T, Hasegawa K, Nagasako K. Squamous cell metaplasia without dysplasia of the colonic mucosa in ulcerative colitis. Gastrointest Endosc 1990; 36: 65-66

5 Bujanda L, Iriondo C, Munoz C et al. Squamous metaplasia of the rectum and sigmoid colon. Gastrointest Endosc 2001; 53: 255 256

Bibliography

DOI 10.1055/s-2007-966861

Endoscopy 2008; 40: E45-E46

(c) Georg Thieme Verlag KG Stuttgart · New York . ISSN 0013-726X
Corresponding author

\section{K. Fu, MD, PhD}

Department of Coloproctology

Tokatsu-Tsujinaka Hospital

Chiba 270-1168

Japan

Fax: + 81-4-7184-9854

fukuangi@hotmail.com 